\title{
Value System and Standard of Education in Nigerian Third Generation Universities: Implications for Counselling
}

\author{
Omeje, Joachim Chinweike \& Eyo, Mfon Edet
}

\begin{abstract}
This research was a correlation study of value system and standard of university education in third generation universities in South-South geopolitical zone. It sought to answer five research questions which were derived from the five specific purposes of the study. Five research hypotheses were also formulated and tested. A sample of 200 students were randomly drawn from the population of 7620 first year and final year undergraduates of the Faculties of Education of the University of Uyo and the Rivers state University of Science and Technology, Port Harcourt. The instrument consisted of a Value Measurement Inventory (VMI) and the school record. The data was analysed using mean, Pearson Product correlation coefficient and $t$ test. The findings indicated a significant and positive relationship between the value system of the undergraduates and the standard of university education.

\section{Introduction}

Value is a philosophical concept, diverse in nature and controversial in content. Different schools of thought differ on issues like definition of value, forms/classification of value, subjectivity/objectivity of value, what is of value etc. Despite its controversial nature, it is still widely acknowledged as an influential factor in the affairs of human being. It is reputed to have the ability of influencing human being, propelling them into doing certain things while avoiding doing others. Value is an underlying factor in the concept of choice; it is as intrinsic to human being as rationality; it determines what is cherished or refused; it decides what is rejected or accepted. Little wonder, Carl
\end{abstract}


Rogers defined value as the tendency to show preference (Okafor, 1992).

Value may be positive or negative. This is however a function of the society; as what is considered a positive value in one society may be a negative value in another society. For instance, same-sex marriage, involving gay and lesbian relationships, is seen as a negative value in Nigeria, but it is a positive value in Belgium where same-sex marriage is legalized nation-wide. This position of positive and negative value being a function of the society is with no prejudice to the fact that there are some values that are positive or negative across the different biases-across religious, social, cultural, geographical boundaries etc. Example of such value is the sanctity of human life which is a positive value across different biases.

It suffices to state here that the definition given above encompasses the positive and negative forms of value. It is therefore pertinent to give a description that sifts the positive from the negative forms of value. For a value to be seen as positive both the set goals and the means of attaining them should be good, worthwhile and desirable, socially acceptable and legally permissible. The reverse is negative value. Viewed in this perspective, value encompasses the norms and ethics of any given society. If value has a role to play in setting goals and choosing means of realizing these goals, value therefore has a role to play in the teaching-learning process. Of course, the set goals and the procedures adopted to achieve the goals, in the educational process, influence the outcome of the educational process.

Researchers investigated the relationship between values and academic achievement. In a bold attempt made in this direction, Mogor (1977) investigated the relationship between personal values and scholastic achievement. His findings indicated a positive relationship between personal values of students and their scholastic achievement. This finding however contrasted a similar investigation conducted earlier. Nwachukwu (1974) studied values and academic 
achievement; and his findings indicated no relationship between a student's value orientation and his academic achievement. The variability in these findings provided a justification for another study in this area. In addition, both studies were done at the secondary school level. There was therefore the need to conduct a similar study at the tertiary level of education. These conditions consolidated the need and importance of the present study.

According to the Constitution of the Federal Republic of Nigeria, 1999, dignity of labour, integrity, religious tolerance, and self-reliance amongst other are attributes that are considered as values in the national ethos. That they are cherished as values means that they are positive. The National Policy on Education (NPE) (2004) also specifies values system acceptable in the country and should thus be inculcated in the learners through the quality of educational instruction. These include moral/spiritual values, dignity of human person, self-reliance, and communal responsibility, amongst others. It particularly tasks tertiary institutions to "develop and inculcate proper values" (NPE, 2004:36) implying that there are improper or negative values that should be nipped in the bud.

Furthermore, though the Constitution of the Federal Republic of Nigeria, 1999 and the NPE (2004) specify value system acceptable in the country, it is worth mentioning that the values enshrined in a document or professed openly might differ from what is being practiced or exhibited. These were what Okafor (1992) called conceived and operative values respectively. Specifically, conceived value refers to the ideal values that are professed openly while the real behavioural exhibitions and actions are the operative value. Apart from these two national documents, which give the conceived value of the Nigeria society, researchers also identified the Nigeria value system through the scientific approach. Ella (1993) investigated the value system in Idomaland. His findings showed that "respect for elders, dignity of labour, chastity among women folk, patriotism, hospitality, self-reliance and courage were positive values...in Idoma 
Value System and Standard of Education in Nigerian Third Generation Universities...

traditional value system." This can be extrapolated to represent the value system of a traditional Nigerian society.

However, there has been increasing concerns over the trend of value system in the society generally. In Nigeria, many wondered if the character aspect of assessing a candidate before conferring a degree by Nigerian university on such candidate is still being considered as a serious factor "given the values of graduates in workplace, the incidents of cult violence, examination malpractices etc. that have come to become pronounced aspects of the public view of the contemporary Nigerian university" (Utomi, 2000:260). Pelikan (1992), as cited in Utomi, also comments on this widely spread eroding values. Describing the concern as "university bashing," he observed that it has become so regular that the "bashing" has turn to a cottage industry, "with books bearings such titles as professors and the Demise of Higher Education, Tenured Radicalism: How politics has Corrupted our Higher Education, Killing the Spirit, Illiberal Education, and The Moral Collapse of the University appearing one after the another" (Utomi, 2000:258). Whether these fears are justified or misplaced, they indicate a conscious acknowledgement of the place of value in university education.

In his study, Ella (1993) reported "a wind of change which tend to erode the quality of the Idoma traditional value system" (Ella, 1993:2). Other researchers express similar sentiment on the present Nigerian value system. According to Ukeje (2002), indiscipline and corruption have invaded the strata of our national ethics. He lamented that in today's Nigeria, "ethnicity, lack of patriotism, indiscipline and corruption abound in all strata" (Ukeje, 2002:20). In the same vein, violence, laxity in sexual morality, obsession for money/materialism etc have been identified as constituting our present day value system (Gana, 2002). President Olusegun Obasanjo added to the weight of the presumptions that there are value crises in our society when he listed corruption, armed robbery, cultism, amongst others as some of the vices threatening the social fabric of the Nigerian society. He 
observed that these contribute to "instability and weakening of all public institutions" (Obasanjo, 2003; Obasanjo, 2003 ${ }^{\mathrm{a}}$; Obasanjo, 1999). These negative values are not only present but seem widespread.

But to what extent has the university been affected by this trend? Some stakeholders were of the view that the university is not faring any better from the fate of the society. There seems to be a popular opinion that educational institutions that were supposed to be the custodians of the cherished values have been invaded and is contaminated by vices such as forgery/admission irregularities, cultism and senseless killings, examination malpractices, nude dressing and shameless indulgence in sophisticated harlotry, amongst others (Amao-kehinde, 2003; Okebukola, 2003; Gana, 2002; Nwana, 2000). A weeklong national Summit on Higher Education "noted the existence of deep-rooted social vices in Nigerian tertiary institutions that include indiscipline, cultism examination malpractice, rape, apathy to work, extortion, excessive unionism amongst others" (Olatunji, 2002).

The public is generally concerned on tertiary education, and university education in particular (Hughes, 1998, Ginkel. 1998). This concern, and the acknowledgement of the place of value in the realization of the goals of education consolidated the justification for this study, which sought to establish the relationship between the value system of the undergraduates and the standard of education in the universities.

As a result of the importance of standard in university education, deliberate measures were taken by different countries to ensure and improve standard (Sim and Idrus, 2004; Mathus, 2001; Department for Education and Skills (DFES), 2001). In Nigeria, while there is a general opinion on the eroding value system, there is a corresponding outcry over the decline in the standard of education Akpofure and N'dupu (2000) listed some factors hindering the maintenance of standard in university education. These included. 
Poorly planned expansion and enrolment, grossly inadequate funding and management of resources, policy instability, inadequate political commitment to quality and to implementation of vital measures and even a lack of real awareness of the impact of certain policy decisions on the system" (Akpofure and N'dupu, 2000: 128).

Researchers and experts also noted the sliding quality of university education. They attributed the state of affairs to divers factors ranging from poor funding, decayed infrastructures, poor teaching quality to inadequate instructional materials. Other factors identified as contributing to the poor quality include poorly paid and poorly trained academic staff, unplanned enrollment expansion, outdated and insufficient equipment, irrelevant curriculum, and irregular school calendar (Achi, 2004; Anwabor, 2003; Nnadozie, 2003; Olatunji, 2002; Ajao, 2001; Ogunleye, 2001; Ogefere, 2001). Quite noteworthy is the fact that few of these experts made mention of personal commitment and value system of the students as a factor in the eroding standard of university education (Ajao, 2001). The research was therefore an identification of the relationship between the value system of the university students and the standard of university education.

\section{Research Questions}

The questions that the researchers posed to guide the study are:

(1) What is the extent of relationship between the value system of the undergraduates and the standard of university education as measured by their academic achievement?

(2) How does the academic achievement of undergraduates with positive value system differ from those with negative value system? 
(3) How does the academic achievement of male undergraduates with positive values system differ from their female counterparts with positive value system?

\section{Research Hypotheses}

Three null hypotheses derived from the research questions were formulated to guide the study. They were formulated and tested at.0.5 level of significance. These include the proposition that:

(1) There is no significant relationship between the value system of the undergraduates and the standard of university education as measured by their academic achievement.

(2) There is no significant difference between the academic achievement by undergraduates with positive value system and those with negative value system.

(3) There is no significant difference between the academic achievement of male undergraduates with positive value system and their female counterpart with positive value system.

The present study is significant in a number of ways. Indeed, the value system of any society determines the dynamics of such society. These dynamics include the process for the fulfilment or otherwise of national yearnings and aspirations. A study that therefore aimed at establishing the relationship between the value system of the undergraduates and the standard of education can therefore be said to be invaluable. Indeed this study is a major contributor to national development as it sought to establish the influence of a crucial factor on the standard of the determinant of national development, which in turn would help to shape the standard for the better.

\section{Methodology}

The study adopted a correlational design. It adopted a correlational design because the study sought to establish the relationship between the value system of the undergraduates and the standard of university education. 
This study was targeted at the third generation universities in the south-south geopolitical zone. The south-south geopolitical zone is one of the six geopolical zones in the Federal Republic of Nigeria. It is made up of six states including Akwa Ibom, Bayelsa, Cross River, Delta, Edo and River States.

There are 54 universities in Nigeria. These include 25 Federal Universities, 19 States Universities, and 10 private Universities. More so, Universities that were established up to 1970 are categorized as first generation Universities. Those that were established between 1971 and 1975 are grouped as second-generation Universities. Other Universities outside the above two categories are seen as third generation Universities. The south-south geopolitical zone has a total of 10 Universities. These include four Federal Universities, four state universities, and two private universities (JAMB 2004). With respect to generation of establishment, the zone has seven third generation universities. However, the study delimited itself to two thirdgeneration universities in the south-south geopolitical zone-the University of Uyo and the River State University Science and Technology Port Harcourt.

The population for this study was the first year and final year students of 2004/2005 academic session in the Faculties of Education in the University of Uyo and the Rivers State University of Science and Technology, Port Harcourt. It included the male and female students of these faculties with no consideration to intelligence, tribe, socioeconomic status or religion.

There were 178 and 3,369 first year students in the University of Uyo and the River State University of Science and Technology respectively in the Faculties of Education for year 2004/2005 academic session. Also there were 194 and 3,879 final year students in the University of Uyo and the Rivers State University of Science and Technology respectively in the Faculties of Education for year 2004/2005 academic session. Therefore, the population of this study was 7620 first year and final year students in the Faculties of 
Education of the two universities as described above (data obtained personally from the Education Faculty Officers of the two universities).

The sample of this study was two hundred first year and final year students in the Faculties of Education of the University of Uyo and the River State University of Science and Technology. This was made of one hundred students in each of the revels in the two Universities. The students were drawn through simple random sampling.

At each of the levels in each of the schools, the researcher liaised with a lecturer handling a faculty course that was compulsory to all the students in the affected level. At the time for such lecture, the researcher joined the lecturer to the class. When the students were seated, equal sizes of paper, already cut and labelled up to 50 and the rest left blank, were presented to the students to pick. Those that picked the labelled ones were taken as the sample. This procedure was used for both the first year and final year students in the affected universities.

More so, first year and final year students from the Faculty of Education in these universities were chosen for this study via stratified random sampling. The first year and the final year students are in the "transition state" in the universities. The first year witnessed transition from the society to a university life, while the final year students transit from the university to the reality of life in the society. They were therefore viewed as a good combination for a research that has to do with values, a concept that has influence on both the university and the society. Simple random sampling was used in choosing the two universities.

\section{Instrument}

The instrument used in this study was a questionnaire called Value Measurement Inventory (VMI). This instrument was used to elicit data on the value scores of the students. School continuous assessment 
record was used to get the academic achievement scores of the students.

The researchers for this study developed the VMI. It has three sections, named A, B, and C. The first section is an introductory note that introduced the questionnaire to the respondents. The second section elicited from the respondents' data on personal information and location. This included the university, gender of the respondent, year of study etc. The last section is a 15-item construct that elicited information on the values scores of the respondents. The section $\mathrm{C}$ of the VMI is a Likert-like scale of measurement but with four points on the scale. These four options formed the scoring pattern of the instrument. Strong concurrence with the position of an item on the questionnaire was given as STRONGLY AGREE and had a maximum of one point; thus was followed by AGREE, two points, DISAGREE, three points; while STRONGLY DISAGREE had four points. These points were utilized in statistically manipulations, which provided the bases for answering the research questions and testing the hypotheses.

Furthermore, the academic achievement of the respondents was obtained on the continuous assessment score of one of the compulsory general courses in the faculty. Where the scores were more than one the average performance was taken. Moreso, where there was no continuous assessment score, a lecturer handling a general course in the faculty was encouraged to administer a test on the students; the scores of which was used as the academic achievement of the respondents. The continuous assessment score was converted to percentage to serve as the academic achievement of the respondents.

\section{Reliability of the Instrument}

In order to ascertain the reliability of the instrument, the VMI was administered on 20 final year students of the Department of Educational Foundations, University of Nigeria, Nsukka. The data generated was tested with Cronbach statistics, and the reliability was found to be 0.87 . The internal consistency of the VIP was therefore adjudged to be reliable. 


\section{Procedures}

The instrument was administered by the researchers on the sampled population in the different universities. The researchers personally approached the Faculty Officers of the Faculty of Education in the two universities and asked for approval to administer the questionnaire on the first and final year students of the 2004/2005 academic session. On getting the approval, the researchers then met a lecturer in the faculty that was handling one of the faculty courses that involve the entire students in the respective levels. At the time of such lecture, the researchers joined the lecturer to the venue of the lecture. When the students were all seated, the researchers liaised with the lecturer to compose the sample as described earlier. After the composition of the sample, the lecturer then introduced the researchers who addressed the respondents, explained the purpose and importance of the study, assured them of confidentiality, before administering the questionnaire to them. The researchers administered the questionnaire personally. This direct delivery technique had the multiple advantages of ensuring large scale return of the questionnaire.

The researchers also got the continuous assessment score of the respondents on the affected course from the affected lecturers. Where the scores were more than one, the average score was used; and where there was none, the lecturer was encouraged to administer a test on the students. This served as a measurement of the academic achievement of the respondents.

The data gathered and collated were analyzed using Pearson's Product Moment correlation coefficient, means and standard deviation, to provide answers to the research questions.

Based on the four-point scale of the VMI, 2.50 was used as the criterion value. The value score for each respondent was the mean score of the respondent to the items on the VMI. This mean was then compared with the criterion value to decide on which respondent had a positive or negative value. If a respondent had a mean score of 2.50 or below, such respondent was considered as having a negative value 
system; if the respondent had a mean score above 2.50 , the respondent was considered as having a positive value system.

The t-test was used in testing the formulated hypotheses two and three at .05 level of significance, while Pearson product moment correlation matrix was used to test hypothesis one at .01 level of significance

\section{Results}

\section{Research Question 1}

The results of the analysis of research question 1 showed that there was a strong and high relationship between the value system of the undergraduates and the standard of university education as measured by their academic achievement. From the presentation in the table 1, it is quite clear that there is a strong and high relationship between the value system of the undergraduates and the standard of university education as measured by their academic achievement. This is discernible from the Pearson product moment correlation coefficient (r) of 0.713 , which indicates high relationship. The relationship can also be explained using the coefficient of determinate, represented as $r^{2}$. The $r^{2}$ of $50.8 \%$ implies that the value system of the undergraduates account for $50.8 \%$ of their academic achievement. The significance of this relationship can be established by testing for the hypothesis derived from research question 1

The Pearson correlation coefficient for the relationship between the two variables is .713. It is also shown in the table 2 that the probability is .000 while .0 .5 is the level of significance. Since the probability is less than the alpha, the null hypothesis that there is no significant relationship between the value system of the undergraduates and the standard of university education as measured by their academic achievement is rejected.

\section{Research Question 2}

The results of the analysis of the research question 2 showed that the academic achievement of undergraduates with positive value system differs from those with negative value system. Also the formulated 
hypothesis used to throw more light on the question showed that there was significant difference between the academic achievement of undergraduates with positive value system and those with negative value system.

As indicated in table 3, from the sample of 200 undergraduates used for the study, 143 were identified as having positive value system, while 57 had negative value system. The mean of academic achievement of those with positive value system was 70.17 while 43.86 was the mean academic achievement of those with negative value system. It was clear that the academic achievement of undergraduates with positive value system differs from those with negative value system, while an average student with positive value scored about 70 , only 44 was scored on an average by student with negative value system. The mean difference of 26.32 was quite a big difference. This research question was transformed into a hypothesis, whose test is shown on table given.

The table 4 as could be seen showed that the degree of freedom for the data presented was 198 while 20.29 was the t-calculated. The exact probability of the calculation is .000 at .05 level of significance. Since the probability is less than the alpha, the null hypothesis that there is no significant difference between the academic achievement of undergraduates with positive value system and those with negative values system is rejected.

\section{Research Question 3}

The results of the analysis of research question 3 showed that there exist a difference in the academic achievement of male undergraduates with positive value system and that of their female counterpart also with positive value system, with the males performing better. Also, the hypothesis revealed that there was no significant difference between the academic achievement of male undergraduates with positive value system and their female counterparts with positive vale system. 
From table 5, a total of 143 undergraduates were identified as having positive value system. This number included 49 males and 94 females. The mean academic achievement for the males with positive value system was 71.22 while that of the female was 69.63. The data indicated a mean difference of 1.60 , which cannot be said to be a big difference. This difference implied that there exists a difference in the academic achievement of male undergraduates with positive value system and that of their female counterparts also with positive value system; with the male undergraduates performing better. However, the statistical significance or otherwise of this difference can best be determined by testing the third hypothesis.

Table 6 presents a t-test calculated for the academic achievement of 49 male and 94 female undergraduates with positive value system. With a degree of freedom of 141 , the $t$ is 1.81 at .05 level of significance. The null hypothesis that there is no significant difference between the academic achievement of male undergraduates with positive value system and their female counterparts with positive value system is upheld as the probability was greater than alpha.

\section{Discussion}

The research questions, which guided the study, centered on the extent of relationship between the value system of the undergraduates and the standard of university education as measured by their academic achievement, how the academic achievement of undergraduates with positive value system differ from those with negative value system, and how the academic achievement of male undergraduates with positive value system differ from their female counterparts with positive value system. The result of the above research questions are as discussed as follows.

The Relationship between the Value System of the Undergraduates and Standard of University Education

The first finding of the study was the answer to research question one, which was also transformed into a hypothesis and properly tested. 
This research question sought to find out the extent of relationship between the value system of the undergraduates and the standard of university education as measured by their academic achievement? The finding indicated that the extent of the relationship was high, with value system accounting for about $51 \%$ of the academic achievement of the undergraduates. This high relationship between the value system of the undergraduates and the standard of university education was also tested and known to be statistically significant. This statistically significant, strong and high relationship between the value system of the undergraduates and the standard of university education as measured by their academic achievement, as indicated by this study, contradict the findings of Nwachukwu (1974). The said findings by Nwachukwu indicated that there was no relationship between the value orientation of students and their academic achievement. The first finding however corroborated and supportd the findings of Mogor (1977). In his own study, Mogor discovered a positive relationship between personal values of students and their scholastic achievement.

Academic achievement of undergraduates with positive value system and those with negative value system

The second finding of this study emerged in an attempt to provide answer to research question two. The said research question sought to find out if the academic achievement of the undergraduates with positive value system differs from those with negative value system. The second finding indicated that the academic achievement of undergraduates with positive value differ from those with negative value system. It also indicated that the difference between the academic achievement of undergraduates with positive value system and those with negative value system was significant, implying that the difference was not due to chance. This finding consolidated the first finding. It established that not only was there a positive and strong association between value system and academic achievement of undergraduates but also that those with positive value system perform academically better than those with negative value system. If 
there was a statistically significant difference between the academic achievement of undergraduates with positive value system and those with negative value system, it therefore implied that the value system was strongly related to academic achievement. This finding was at variance with the findings of Bassey (1991). Bassey sought to find out the relationship between discipline and academic performance of secondary school students and discover that there was no statistically significant difference between the academic performance of undisciplined and disciplined students. But the findings of this present study agreed and supported the finding of Etuki (1989) and Stephen (1977). Stephen noted in his findings that students who exhibited socially acceptable conduct performed significantly better than those with poor behaviour and conduct. On his part, Etuki discovered in his study that disciplined students performed better academically than undisciplined students. It was quite obvious that socially acceptable conduct and discipline on the one hand, and poor behaviour and discipline on the other hand can be taken to represent positive and negative value systems respectively.

The academic achievement of male undergraduates with positive value system and their female counterparts with positive value system

Furthermore, the study also gave finding with respect to gender difference on value and standard of education. The third finding indicated that there exists a difference, though small, in the academic achievement of male undergraduates with positive value system and that of their female counterparts also with positive value system; with the male undergraduates performing better. It also established that this difference between the academic achievement of male and female undergraduates with positive value system is not statistically significant, and can thus be ignored and regarded as being due to chance. Gender was therefore not a factor on the extent of the relationship between the value system of the undergraduates and standard of university education. This meant that the positive relationship between the value system and standard of university education would hold no matter which gender was involved; meaning 
that a male or female student with positive value system would perform academically better than the counterpart of any gender with negative value system. This finding indisputably help in generalizing the findings of this study across the gender divide. This finding agreed with the findings of Bassey (1991) on the influence of gender factor on the relationship between indiscipline and academic performance of secondary school students. Bassey reported that there was no significant difference between the academic performance of undisciplined male and female students.

\section{Implication and Recommendations}

The findings of this study have far-reaching implications for education. It has established that there was a significant and positive relationship between the value system of the undergraduates and the standard of university education. The hue and cry over low standard of university education implies that the value system of the undergraduates is negative. The implication of this is that the curriculum contents of university education may not have been fashion out to deliberately support the acquisition of positive value system. It also implied that where there was such provision in the curriculum, the objective has not been realized.

Another implication of the findings of this study was that poor standard of university education was traceable to the preponderance of negative value system amongst the undergraduates. This can be extrapolated to mean that the universities may have taken the issue of value with levity. This is confirmed by the public alarm on the fate of university education, an indication that all was not well with the value system of the undergraduates.

The present study was limited by the difficulty of not only getting the respondents to attend to the questionnaire but also gathering them to write a continuous assessment test where none had been given already. Furthermore, the results could have been different if the influence of socio economic status on the relationship between value 
system and standard of university education was included in the variables investigated. The researchers then suggest such area for further research.

Equally, the study recommends that the National Orientation Agency (NOA), the agency of government that is vested with the issue of value reorientation amongst others, should liaise with the different institutions of learning to come up with efficacious value reorientation programmes targeted at not only the students but the Nigerian citizenry.

\section{References}

Ajao, W. (2001). "How to Restore Quality to Varsities." Vanguard, 5th July, p 14.

Akpofure, R. E.O. \& N'dupu, B.L. (2000). "National Standards and Quality Control in Nigerian Education." In UNESCO, The State of Education in Nigeria. Nigeria: UNESCO Abuja office, 119-131.

Amao-Kehinde, A. O. (2003). "Cult Activities and Campus Violence: Implications for Psychological Counselling." Education Today, 10(2), (December), 36-43.

Anwanbor, D. (2003). "Examination Malpractice and the Degenerative Effects on Quality of Education, Examination/assessment and Certification." Journal of Nigerian academy of education, 1(1), (November), 69-79.

Bassey P.O. (1991) "Effects of Indiscipline on the Academic Performance of Secondary Students in Ugep LGA of Cross River State" Unpublished MED project UNN

Department for Education and Skills (DFES) (2001). The Annual Report of Her Majesty's chief Inspector of schools htt:/www.officialdocuments.co.uk/document/ofsted/hc500/35204.htm Retrieved on 08/09/04

Etuki, D. E. (1989) "Indiscipline and Its Influence on Academic Performance amongst Secondary School Students in Obubra LGA of Croos River State" Unpublished thesis

Ella, I.O.A, (1993) "Value System in Idomaland: Implications for Western Education" Unpublished Ph.D Dissertation. UNN

Federal Republic of Nigeria. (2004). National Policy on Education (4th Ed). Lagos: NERDC Press. 
Federal Republic of Nigeria. (1999) Constitution of the Federal Republic of Nigeria 1999. Lagos: Federal Government Press.

Gana, J. (2002). "Redefining our National Values under a New Ethical Revolution." Education Today, 9(2), (Dec.) 4-8.

Ginkel, H. (1998). "Preparing for a Sustainable Future: Higher Education and Sustainable Human Development" In UNESCO, Higher Education in the Twenty-first Century: Vision and Action. Paris: UNESCO.

Hughes, P. (1998). "The Contribution of Higher Education to the Education System as a Whole" In UNESCO, Higher Education in the Twentyfirst Century: Vision and Action. Paris: UNESCO.

JAMB (2004). "List of Universities and Degree Awarding Institutions in

Nigeria." http://www.jambng.com/brochure/ume/institutions. Retrieved on $19 / 11 / 04$

Obasanjo, O. (1999). The new dawn: inaugural speech by His Excellency President Olusegun Obasanjo following his swearing-in as President of the Federal Republic of Nigeria. Abuja: National Orientation Agency. , (2003a). "Fast Forward into the Future." http://www.nigeriavillagesquarel.com/obj.htm. Retrieved on 19/08/04 ,(2003b). "Reform Programme Central to 2004

Budget”.http:www.nigeriavillagesquarel.com/articles/obj4.html. Retrieved on 29/06/04

Ogefere, S. (2001). "Quack Teachers Produce Half-baked Students." The Guardian, 18th March, p 16.

Ogunleye, B. (2001). "Experts Lament Sliding Quality of Today's Graduate." The Guardian, 11th September, p 29.

Okafor, F. C. (1992). Philosophy of Education and Third World Perspective. Virginia: Brunswick Publishing Company.

Okebukola, P. (2003). "Control and Eradication of Secret Cults in Higher Institutions in Nigeria." Education Today; 10(2), (Dec.), 10-14.

Olatunji, B. (2002). "Repositioning Higher Education in Nigeria." Thisday, 20th March, p 54.

Pelican, J. (1992). "The Idea of a University: A Re-examination.” In Utomi, P. (2000), Critical Perspectives on Nigerian Political Economy and Management. Ibadan: Spectrum Books Limited.

Sim, H. K. C. \& idrus, R. M. (2004). "A Study of Quality Assurance Practices in the Universities Sains Malaysia (USM), Malaysia." Turkish Online Journal of Distance Education-TOJDE, 5(1). 
Retrieved on 08/09/04 from http:/tojde.anadolu.edu.tr/tojde13/pdf/idruspdf.pdf

Stephens, T.N. (1977). Teaching Skills to Children with Learning and Behaviour Disorder. Columbus: A Bell and Howell company.

The Post Express (2001). "Troubled University System." (editorial), 29th October p. 34.

Ukeje, F.E. (2002). "National Ethics and Social order." Education Today, 9(2) (Dec.), 20-25.

Utomi, O.E. (1984), P. (2000). Critical Perspectives on Nigerian Political Economy and Management. Ibadan: Spectrum Books Limited.

Table 1: The relationship between vale system and standard of university education of undergraduates

\begin{tabular}{|l|l|l|l|l|}
\hline Groups & Number & $\mathrm{r}$ & $\begin{array}{l}\text { Coeff of } \\
\text { determinate } \\
\mathrm{r}^{2}\end{array}$ & Inference \\
\hline $\begin{array}{l}\text { Value } \\
\text { scores }\end{array}$ & 200 & .713 & $\begin{array}{l}\mathrm{R}^{2}=\mathrm{r}^{2} \times 100 \\
=50.8 \%\end{array}$ & $\begin{array}{l}\text { Relationship } \\
\text { is high }\end{array}$ \\
\hline CAS & 200 & & & \\
\hline
\end{tabular}

Key: CAS - continuous Assessment score

Table 2: The significance of the relationship between the value system of the undergraduates and standard of university education

\begin{tabular}{|l|l|l|l|l|l|l|}
\hline Groups & No & r & $\alpha$ & $\mathrm{P}$ & Decision & Inference \\
\hline $\begin{array}{l}\text { Values } \\
\text { score }\end{array}$ & 200 & $.713 *$ & .010 & .000 & Reject $\mathrm{H}_{\mathrm{O}}$ & $\begin{array}{l}\text { Correlation } \\
\text { is } \\
\text { significant }\end{array}$ \\
CAS & 200 & & & & & \\
\hline
\end{tabular}

* Correlation is significant at the 0.5 level (2- tailed) 
Table 3: The mean and standard deviation of academic achievement of undergraduates with positive and negative value system

\begin{tabular}{|l|l|l|l|l|l|}
\hline Groups & No & Mean & SD & $\begin{array}{l}\text { Mean } \\
\text { difference }\end{array}$ & SE \\
\hline Positive values & 143 & 70.17 & 7.72 & 26.32 & 1.30 \\
\hline Negative values & 57 & 43.86 & 9.54 & & \\
\hline
\end{tabular}

Table 4: The significance of difference between academic achievement of undergraduates with positive value system and those with negative value system

\begin{tabular}{|l|l|l|l|l|l|l|l|l|l|l|}
\hline Groups & No & Mean & SD & df & T & $\alpha$ & P & SE & Decision & Inference \\
\hline $\begin{array}{l}\text { Positive } \\
\text { values }\end{array}$ & $\begin{array}{l}14 \\
3\end{array}$ & 70.17 & 7.72 & 198 & 20.29 & .05 & .000 & 1.30 & $\begin{array}{l}\text { Reject } \\
\mathrm{H}_{\mathrm{O}}\end{array}$ & $\begin{array}{l}\text { There is } \\
\text { Significant } \\
\text { difference }\end{array}$ \\
\cline { 1 - 2 } $\begin{array}{l}\text { Negative } \\
\text { values }\end{array}$ & 57 & 43.86 & 9.54 & & & & & & & \\
\hline
\end{tabular}

Table 5: The mean and standard deviation of academic achievement of male and female undergraduates with positive value system

\begin{tabular}{|l|l|l|l|l|l|}
\hline Groups & No & Mean & SD & Mean difference & SE \\
\hline Males & 49 & 71.22 & 7.69 & 1.60 & 1.36 \\
\cline { 1 - 4 } Females & 94 & 69.63 & 7.73 & & \\
\hline
\end{tabular}

Table 6: The significance of difference between the academic achievement of male undergraduates with positive value system and their female counterparts with positive value system

\begin{tabular}{|c|c|c|c|c|c|c|c|c|c|c|}
\hline Groups & No & Mean & SD & $\mathrm{df}$ & $\mathrm{T}$ & $\alpha$ & $P$ & SE & Decision & Inference \\
\hline Males & 49 & 71.22 & 7.67 & 141 & 1.18 & .05 & .242 & 1.36 & $\begin{array}{l}\text { Accept } \\
\mathrm{H}_{\mathrm{O}}\end{array}$ & $\begin{array}{l}\text { Difference } \\
\text { is not }\end{array}$ \\
\hline Females & 94 & 69.63 & 7.73 & & & & & & & \\
\hline
\end{tabular}

